\title{
The impact of aquaculture soundscapes on whiteleg shrimp Litopenaeus vannamei and Atlantic salmon Salmo salar
}

\author{
Matthew Slater ${ }^{1, *}$, Enno Fricke ${ }^{1}$, Monika Weiss $^{1}$, Anja Rebelein ${ }^{1}$, Mirko Bögner $^{1}$, \\ Mark Preece ${ }^{2}$, Craig Radford ${ }^{3}$
}

\author{
${ }^{1}$ Alfred-Wegener-Institute Helmholtz Center for Polar and Marine Research, Am Handelshafen 12, \\ Bremerhaven 27570, Germany \\ ${ }^{2}$ NZ King Salmon Ltd, 93 Beatty Street, Tahunanui Nelson 7011, New Zealand \\ ${ }^{3}$ Auckland University, Leigh Marine Laboratory, Institute of Marine Science, Auckland University, PO Box 349, \\ Warkworth 0941, New Zealand
}

\begin{abstract}
Research into the effects of soundscapes on aquaculture species in key production systems is sparse, despite potential impacts of sound on animal welfare and commercial yields. In the following study, 2 high-value global aquaculture species, whiteleg shrimp Litopenaeus vannamei and Atlantic salmon Salmo salar, were exposed to aquaculture production system soundscapes. For shrimp, sound recordings of a commercial recirculating aquaculture system (RAS) were played back at a sound pressure level (SPL) of $128 \mathrm{~dB}$ re $1 \mu \mathrm{Pa}$, and for salmon, recordings from a commercial sea pen production system were played back at an SPL of $127 \mathrm{~dB}$ re $1 \mu \mathrm{Pa}$ for an 8 wk period. Effects of exposure on growth, survival, and indications of metabolic stress were measured as parameters of interest for aquaculture production. Mean growth performance and survival rates did not differ significantly between sound and control treatments for either species. Blood and haemolymph parameters from both species indicated no measurable change in metabolic status or stress levels. Slight, but non-significant, increases in total haemocyte count and, in particular, hyaline cell count were recorded in shrimp exposed to sound. Slight, but non-significant reductions in overall weight gain were recorded in sound-exposed salmon. Overall, the results indicate that sound exposure in current production systems does not negatively affect the early grow-out stage of these key species, either due to rapid habituation or higher hearing thresholds of hatchery-produced individuals, and that no measurable stress response occurs in sound-exposed animals. In future studies, response of the studied species to acute sound exposure and the response of earlier, and potentially more sensitive, life-stages will need to be determined to ensure optimal welfare and production performance.
\end{abstract}

KEY WORDS: Noise $\cdot$ Stressor $\cdot$ RAS $\cdot$ Sea pen $\cdot$ Pond

\section{INTRODUCTION}

Understanding and managing the effects of multiple stressors in aquaculture systems is central to ensuring efficient and humane production (Ashley, 2007, Lucas \& Southgate 2012). Anthropogenic sources of underwater sound are potentially high-

${ }^{*}$ Corresponding author: mslater@awi.de impact stressors in aquaculture environments and cannot be avoided by cultured animals (Popper 2003). Soundscapes in aquaculture systems have been shown to exceed both the physiological and behaviourally determined hearing thresholds of numerous vertebrate and invertebrate aquaculture species (Bart et al. 2001, Ladich \& Fay 2013, Radford

() The authors 2020. Open Access under Creative Commons by Attribution Licence. Use, distribution and reproduction are unrestricted. Authors and original publication must be credited. 
\& Slater 2019). Despite this, the growth, immune and stress response of key species to sound exposure in various commercial aquaculture production systems remains poorly investigated.

The acoustic habitats prevailing in recirculating aquaculture systems (RAS) and sea pens are highly variable, and the majority of the sound energy falls within the 100 to $500 \mathrm{~Hz}$ range, at or above fish hearing thresholds (Bart et al. 2001, Craven et al. 2009, Radford \& Slater, 2019). Radford \& Slater (2019) showed that RAS and sea pen sound levels exceed the hearing thresholds of the commonly cultured fish common carp Cyprinus carpio (Popper 1972), Atlantic salmon Salmo salar (Hawkins \& Johnstone 1978) and European perch Perca perca (Wolff 1967), while the sound levels of aquaculture pond systems exceed the hearing thresholds of common carp (Amoser \& Ladich 2005). Effects of long-term exposure, relevant to outgrowing aquaculture are unknown.

Sound response in non-mammalian aquatic species has primarily been investigated in short-term exposure experiments playing back extreme anthropogenic noise levels exceeding $170 \mathrm{~dB}$ re $1 \mu \mathrm{Pa}$ (e.g. from pile-driving, boats and air guns [seismic surveys]). These have been shown to alter fish and crustacean (whiteleg shrimp Litopenaeus vannamei and common shrimp Palaemon serratus) behavior and physiology, i.e. avoidance (Feist 1991, Sand et al. 2000, Filiciotto et al. 2016, Zhou et al. 2016), and to decrease fish growth (Filiciotto et al. 2013), severely damage hearing capacity (McCauley et al. 2003) and increase physiological indicators of stress (Wysocki et al. 2006). The effects may impact aquaculture production efficiency. More recently, playbacks of offshore soundscapes (boat noise) and onshore (concrete tank) aquaculture environments have been shown to significantly affect oxidative status and immune stress indicators in juvenile sea bream Sparus auratus (Francesco et al. 2017). However, animals may acclimatise to sound exposure within weeks or months, as has been shown with repeated playback of impulsive sound to European seabass Dicentrarchus labrax (Neo et al. 2018) and ship noise to threespot dascyluss Dascyllus trimaculatus (Nedelec et al. 2016).

In the present study, sea pens and RAS soundscapes were chosen for exposure playback experiments. Sea pen systems dominate marine finfish production worldwide totaling $>5$ million metric tonnes for Atlantic salmon, European seabass, sea bream and Atlantic bluefin tuna Thunnus thynnus. Commercial use of RAS systems is rapidly expanding for the production of early stages of many finfish species, along with full-cycle production of salmonids, other high-value finfish and shrimp species (Joenson 2016, Slater 2018).

Animals are exposed to single or a series of soundscapes throughout their production in aquaculture, and acoustic habitats may influence animal behaviour, metabolic status or immune status. This could lead to changes in feeding success, growth performance, immune response and even survival. In the present study, passive acoustic recordings from offshore sea cages and onshore RAS were played back in controlled holding tanks at relatively high sound levels to Atlantic salmon and whiteleg shrimp, 2 aquaculture species of very high commercial value. Parameters applied to measure aquaculture performance and animal welfare, growth, survival and standard measures of metabolic and immune response were measured after an $8 \mathrm{wk}$ experimental period.

\section{MATERIALS AND METHODS}

All methods applied were approved by the ethics officer of the Alfred Wegener Institute and registered with the Senator of Health's Veterinary Authority Bremen, Germany, in accordance with the EEC Directive 86/ 609 and EU Directive 2010/63/EU.

\subsection{Shrimp system}

Postlarvae whiteleg shrimp Litopenaeus vannamei were sourced from a commercial hatchery in Florida, USA and on-grown in a RAS system at the Alfred Wegener Institute's (AWI) Center for Aquaculture Research in Bremerhaven, Germany. Water salinity in the holding system was maintained at 20 psu and temperature at $28.5^{\circ} \mathrm{C}$ until inclusion in the experiment. Juvenile shrimp were weighed to the nearest $0.01 \mathrm{~g}$ after excess water was removed by blotting. The shrimp were allocated to 6 groups of 50 individuals with a mean $( \pm 1 \mathrm{SD})$ weight of $5.79 \pm 1.54 \mathrm{~g}$ (min. group mean: $5.58 \pm 1.67 \mathrm{~g}$, max. group mean $6.18 \pm$ $1.49 \mathrm{~g})$.

The groups of 50 shrimps were randomly allocated to 6 experimental tanks (dimensions $1.0 \mathrm{~m} \times 1.0 \mathrm{~m} \times$ $0.7 \mathrm{~m}, \mathrm{~L} \times \mathrm{W} \times \mathrm{H}$, water depth of $0.6 \mathrm{~m}$ ) and supplied with water at a rate of $10 \mathrm{l} \mathrm{min}^{-1}$ (complete water exchange time, ca. $1 \mathrm{~h}$ ). The natural light cycle was maintained throughout the experiment. The specially designed RAS consisted of the 6 freestanding 6001 tanks combined with a RAS water treatment 
system maintained $3 \mathrm{~m}$ from the closest tanks (total system volume $3.8 \mathrm{~m}^{3}$ ) including a mechanical solids filter, nitrification biofilter and UV sterilisation. Physical water parameters (oxygen, $\mathrm{pH}$, temperature and salinity) were measured daily. Concentrations of $\mathrm{NH}_{3} / \mathrm{NH}_{4}{ }^{+}, \mathrm{NO}_{3}{ }^{-}$and $\mathrm{NO}_{2}{ }^{-}$, were determined twice per week using a QuAAtro 39 Continuous Segmented Flow Analyzer (SEAL Analytical). Animals were fed Crevetec Grower 1A sinking commercial shrimp diet (CreveTec), at a daily feeding ration of $\sim 3 \%$ of shrimp bodyweight as calculated and adjusted weekly following standard growth tables for whiteleg shrimp.

The 6 experimental tanks were divided into 2 subsystems consisting of 2 parallel rows of 3 tanks. All inflow pipes and outflow pipes were laid separately from the pump manifold to individual tanks and back to the sump to avoid sound transfer between tanks. Water inflows were submerged below the tank water surface to reduce inflow sound disturbance. All pumping, water purification and aeration systems were separated from the tank system by $3 \mathrm{~m}$ PVC piping $(\varnothing 150 \mathrm{~mm}$ ) and all potential tank sound sources were excluded. In all 6 tanks, a single UW30 underwater speaker (Lubell Labs, USA) was hung in the tank center at $25 \mathrm{~cm}$ below the water surface. In the 3 'exposure' tanks, speakers were connected to an $800 \mathrm{~W} 12 \mathrm{~V} 4$ channel amplification system (Mac Audio, Germany) and (continuous) playback of WAV files was conducted with a commercial MP3 / WAV audio player (ClipSport, SanDisk, USA) through the amplification system with the same series of looped snippets played to each separate exposure tank as per methods described by Filiciotto et al. (2013, 2016).

\subsection{Shrimp sound exposure}

Radford \& Slater (2019) recorded $72 \mathrm{~h}$ of RAS noise from 3 locations (close to pump house; middle of tank; close to office) from $0.7 \mathrm{~m}$ deep concrete tanks at the Garnelen Farm Grevesmühlen, Germany. One hundred random $20 \mathrm{~s}$ broadband (0.02 to $24 \mathrm{kHz}$ ) 'snippets' were selected from the 3 hydrophone recordings and looped for playback using multiple recordings over different time frames and days as suggested by Slabbekoorn \& Bouton (2008). Playbacks were calibrated using ST300 hydrophone (Oceaninstruments; flat frequency response $20 \mathrm{~Hz}$ to $60 \mathrm{kHz}$ ) at $48 \mathrm{kHz}$ giving an upper analyzable frequency limit of $24 \mathrm{kHz}$. All hydrophones were calibrated using a sound calibrator (G.R.A.S. Type 42AB) producing a $1 \mathrm{kHz}$ signal at $114 \mathrm{~dB}$ re $1 \mu \mathrm{Pa}$. Full bandwidth (50 Hz to $24 \mathrm{kHz}$ ) sound pressure level (SPL) was adjusted to $128 \mathrm{~dB}$ re $1 \mu \mathrm{Pa}$ in treatment tanks and maintained for $8 \mathrm{wk}$. This level was selected to represent maximum root mean squared (RMS) levels measured at the shrimp farm over a $24 \mathrm{~h}$ period (Radford \& Slater 2019). In control tanks, speakers were not connected to a sound-producing device and sound level in control tanks was, however, determined as for exposure tanks. Recorded sound level in control tanks was $95 \mathrm{~dB}$ re $1 \mu \mathrm{Pa}$ (Fig. 1A).

\subsection{Shrimp sampling}

After $8 \mathrm{wk}$, all animals were harvested and placed into an ice slurry for further analysis, weighed to the nearest $0.01 \mathrm{~g}$ and length measured to the nearest $0.1 \mathrm{~mm}$. Haemolymph was extracted at harvest individually from 3 animals per tank (9 samples per treatment) to determine total haemocyte count (THC), haemocyte type and phenoloxidase activity. Syringes were filled with $100 \mu \mathrm{l}$ of sterile EDTA-free buffer (27 mM trisodium citrate, $385 \mathrm{mM}$ sodium chloride, 115 mM glucose, pH 7.5) (Huang et al. 2010), and an equal amount of haemolymph was withdrawn (1:2 dilution) from the ventral sinus. Individual samples were kept on ice before they were centrifuged at $4^{\circ} \mathrm{C}$ and $800 \times g$ for $10 \mathrm{~min}$. Supernatant was frozen at $-80^{\circ} \mathrm{C}$ until further analysis. To avoid pyrogen effects in phenoloxidase activity determination, all consumables were autoclaved.

Phenoloxidase was determined by formation of dopachrome from L-DOPA analyzed kinetically using an Infinite 200 PRO spectrophotometer (Tecan) applying technical triplicate measurement. Activity measurements were performed after Huang et al. (2010), modified for a 96 well microtiter plate with $10 \mu$ diluted plasma sample added to $215 \mu \mathrm{L}$ DOPA solution $\left(3 \mathrm{mg} \mathrm{ml}^{-1}\right.$ in $0.1 \mathrm{M}$ potassium phosphate buffer, $\mathrm{pH}$ 6.6). Absorption at $490 \mathrm{~nm}$ was recorded every $20 \mathrm{~s}$ for $200 \mathrm{~s}$. All measured activities were plotted against time, and replicates were excluded from analysis where activity development over the measurement period tended to the non-linear (linear regression $r^{2}<0.8$ ). One unit of enzyme activity (U) is defined as a linear increase in absorbance of 0.001 per min per $\mathrm{ml}$ haemolymph.

Total haemocyte count (THC) and differential haemocyte count (DHC) were determined by flow cytometric analysis after Owens \& O'Neill (1997) 


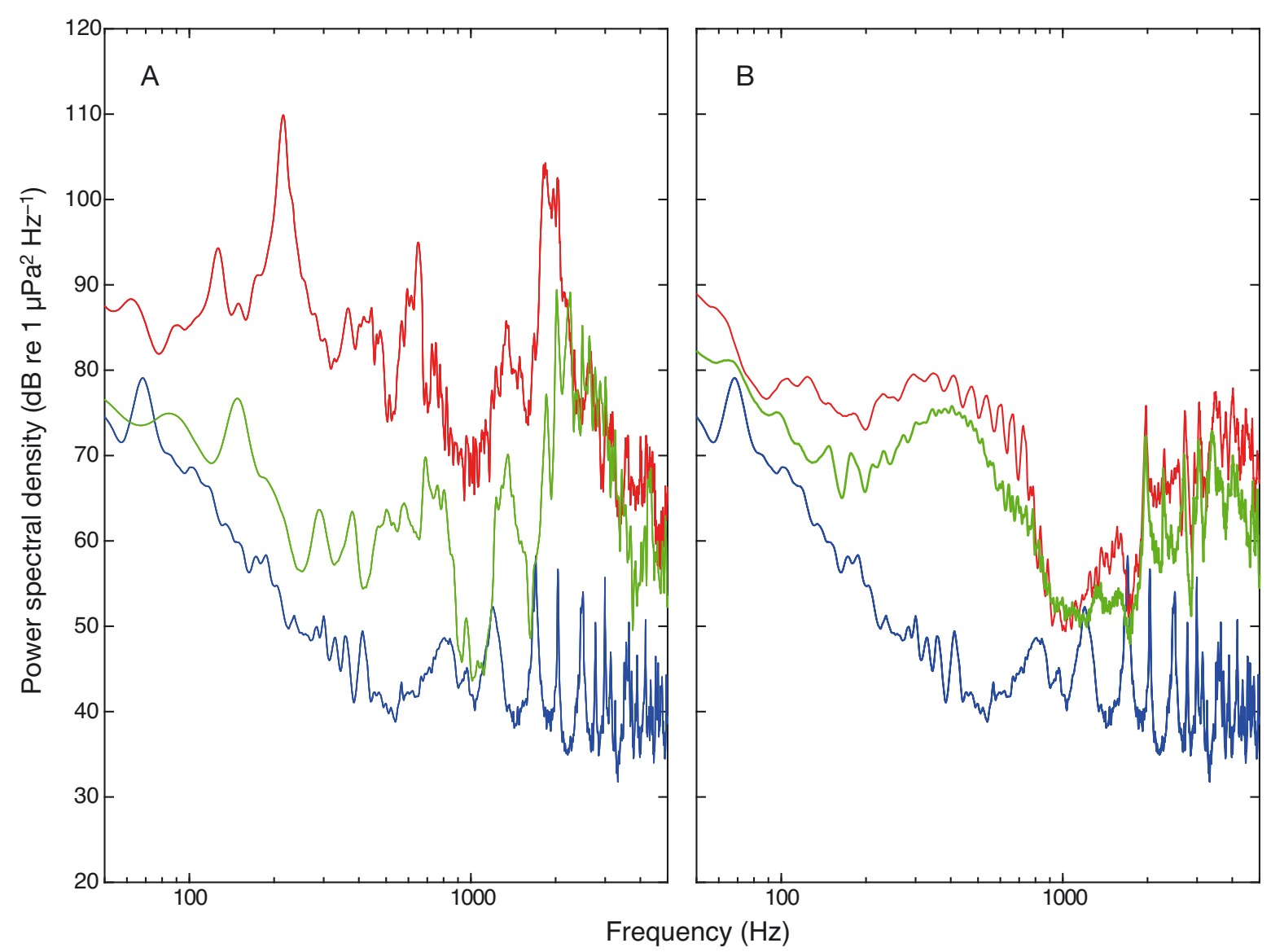

Fig. 1. Mean power spectral densities $\left(\mathrm{dB}\right.$ re $1 \mu \mathrm{Pa}^{2} \mathrm{~Hz}^{-1}$ ) for ambient sound (blue line), playback sound (red line) and source sound (green line) for (A) whiteleg shrimp Litopenaeus vannamei and (B) Atlantic salmon Salmo salar sound exposure

using a BD Accuri C6 (Becton-Dickinson). Samples were analyzed using forward scatter (FSC), proportional to cell size, and side-scatter (SSC), correlating with granularity or interior structure of the cell. Between 30000 and 120000 events were recorded per sample, depending on the cell density in the sample and the cell sub-population dispersal. Before measurement, haemocyte samples were filtered through a $45 \mu \mathrm{m}$ syringe filter (to exclude debris). Scatter plots (FSC vs. SSC) were generated for each sample with FSC data at linear and SSC data at log scale (Xian et al. 2009). Grading was performed using the BD Accuri C6 software (v.1.0 2011) to define haemocyte cell types and exclude unwanted events by visual inspection of distinct event clusters in the dot plots. Haemocytes could be divided into 3 sub-populations based on size (hyaline, semigranular and granular cells). The total haemocyte count was obtained by summing the number of cells per $\mathrm{ml}$ of the 3 population subsets (from the DHC) and values were expressed as the number of haemocytes $\left(\times 10^{5}\right) \mathrm{ml}^{-1}$.

\subsection{Salmon system}

Atlantic salmon Salmo salar parr were sourced from a commercial hatchery in Hirtshals, Denmark, at an average weight of $\sim 100 \mathrm{~g}$ and immediately introduced to full saltwater conditions (30 psu and $14.5^{\circ} \mathrm{C}$ ) in a RAS on arrival at AWI. The animals were held in these conditions for a period of $7 \mathrm{wk}$ in tanks (dimensions $2.0 \times 2.0 \times 0.8 \mathrm{~m} \mathrm{~L} \times \mathrm{W} \times \mathrm{H}$, water depth of $0.6 \mathrm{~m}$ ) prior to experimental onset. The holding tank conditions (pump and filter position, inflows, physicochemical water parameters) and prevailing soundscape in the holding system did not differ from the level in the control tanks. At experimental onset, salmon were anaesthetised with MS-222 ( 100 mg $\mathrm{l}^{-1}$ tricaine mesylate), weighed to the nearest $0.1 \mathrm{~g}$ and measured to the nearest $0.5 \mathrm{~cm}$ length. The salmon were allocated to 6 groups with 20 individuals. Mean ( $\pm 1 \mathrm{SD}$ ) weight was $177.9 \pm 34.2 \mathrm{~g}$ across all groups (min. $175.0 \pm 29.4$ g, max. $181.1 \pm 39.3$ g). At experimental onset, 5 individuals of the total remaining salmon that were not assigned to a group were 
anaesthetised and euthanised with an excess dosage of MS-222 $500 \mathrm{mg} \mathrm{l}^{-1}$, and caudal vein blood was collected for further analysis.

The groups of 20 individuals were randomly allocated to the 6 experimental tanks as described above (dimensions $1.0 \times 1.0 \times 0.7 \mathrm{~m} \mathrm{~L} \times \mathrm{W} \times \mathrm{H}$, water depth of $0.6 \mathrm{~m}$ ) supplied with water at a rate of $201 \mathrm{~min}^{-1}$ (complete water exchange time ca. $30 \mathrm{~min}$ ). The light cycle was maintained at $12 \mathrm{~h}$ light: $12 \mathrm{~h}$ dark throughout the experiment; water was maintained at $14.5^{\circ} \mathrm{C}$, and salinity at $30 \mathrm{psu}$.

\subsection{Salmon exposure}

Radford \& Slater (2019) recorded 144 h of sea pen noise from 3 locations (middle of sea pen and 2 locations on the outside of the sea pen) from NZ King Salmon (farm located at Ruakaka Bay, Marlborough Sounds, New Zealand). The farm consists of 12 sea cages with a surface area of 225 to $250 \mathrm{~m}^{2}$ and a depth of $15 \mathrm{~m}$ mounted on a floating barge and floating high-density polyethylene (HDPE) walkway system. Cages were stocked at varying densities and sizes of chinook salmon Oncorhynchus tshawytscha. In addition to the floating structures and the stocked fish, potential sound sources include access vessels, an associated feed barge, oxygen storage, compressed air automated feeders and a temporary handling facility linked to the site. One hundred random $20 \mathrm{~s}$ broadband ( 0.02 to $24 \mathrm{kHz}$ ) 'snippets' were selected from the 3 hydrophone recordings and looped for playback. Playbacks were calibrated using ST300 hydrophone (Oceaninstruments; flat frequency response $20 \mathrm{~Hz}$ to $60 \mathrm{kHz}$ ) at $48 \mathrm{kHz}$ giving an upper analyzable frequency limit of $24 \mathrm{kHz}$. All hydrophones were calibrated using a sound calibrator (G.R.A.S. Type 42AB) producing a $1 \mathrm{kHz}$ signal at $114 \mathrm{~dB}$ re $1 \mu \mathrm{Pa}$. SPL was adjusted to $127 \mathrm{~dB}$ re $1 \mu \mathrm{Pa}$ in treatment tanks and maintained for $8 \mathrm{wk}$. This level was selected to represent maximum RMS levels measured at the salmon farm. In control tanks, speakers were not connected to a sound-producing device and sound level in control tanks was, however, determined as for exposure tanks. Recorded ambient sound level in control tanks was $96 \mathrm{~dB}$ re $1 \mu \mathrm{Pa}$ (Fig. 1B).

\subsection{Salmon sampling}

Animals were fed twice per day with sinking commercial salmonid feed (Skretting Optiline F1-P and
F2-P) ad libitum, 3\% bodyweight as calculated by standard growth tables for Atlantic salmon. After $8 \mathrm{wk}, 3$ animals per replicate were anaesthetised and euthanised with an excess dosage of MS-222 $500 \mathrm{mg}$ $\mathrm{l}^{-1}$, weighed $( \pm 1 \mathrm{~g})$, and measured ( length, $\pm 0.5 \mathrm{~cm}$ ). Blood was collected from the caudal vein and liver weight $( \pm 1 \mathrm{~g})$ determined to calculate the hepatosomatic index (HSI). All remaining animals were anaesthetised with $100 \mathrm{mg} \mathrm{l}^{-1}$, weighed to the nearest gram and measured to the nearest $0.5 \mathrm{~cm}$ length.

Body indices weight and length were used to calculate weight gain $(G$, in $g)$, specific growth rate (SGR, as \% daily body weight gain) and HSI as follows:

$$
\begin{gathered}
G=\text { weight }_{\text {End }}-\text { weight }_{\text {Start }} \\
\text { SGR }=100 \times\left(\text { ln weight }_{\text {End }}-\ln \text { weight }_{\text {Start }}\right) / \mathrm{d} \\
\text { HSI }=\text { Liver weight } / \text { total body weight } \\
\text { K }(\text { Condition Factor })=100 \times \\
\text { (total body weight } \left./ \text { total body length }{ }^{3}\right)
\end{gathered}
$$

\subsection{Blood analyses}

A subsample of $0.5 \mathrm{ml}$ blood from each fish was used for determination of $\mathrm{pH}$ using a IntellicalTM PHC $108 \mathrm{pH}$ sensor (Hach) and blood lactate content to the nearest $0.1 \mathrm{mmol} \mathrm{l}^{-1}$ using a Gemar Lactate Scout automated lactate analyser (Gemar). A second subsample was transferred to capillary tubes H7 812 (Servoprax) to determine haematocrit using a SERVOspin HKT TC-12K haematocrit centrifuge (Servoprax). Samples were spun at $7700 \times g$ for $15 \mathrm{~min}$ and separated haematocrit determined by measuring fraction length and calculating percentage of total. Remaining blood was centrifuged at $2000 \times g$ at $4^{\circ} \mathrm{C}$ to separate the plasma. Plasma glucose was determined by a Fuji Dry Chem NX500i blood autoanalyser with Fuji Dri-Chem Slides GLU-PIII (Fujifilm Europe). Plasma cortisol was determined after Reiser et al. (2010) as adapted by Fuchs et al. (2017) using enzymelinked immunosorbent assays (ELISA) (RE52611, IBL International). A $100 \mu \mathrm{l}$ blood plasma aliquot was denatured at $80^{\circ} \mathrm{C}$ for $1 \mathrm{~h}$, vortex agitated for $20 \mathrm{~s}$, diluted in $0.05 \mathrm{M}$ PBS and vortexed for $20 \mathrm{~s}$ more. Samples were centrifuged at $13000 \times g$ for $20 \mathrm{~min}$ before a $50 \mu \mathrm{l}$ sample of supernatant was used for the ELISA in duplicates, and photometric measurement was conducted with a microtitre plate reader (TriStar LB941 Berthold Technologies). 


\subsection{Statistics}

Growth performance and blood/haemolymph parameter data were analysed for normality (ShapiroWilk's test) and homoscedasticity (Levene test). The individual sample values within tanks which followed a normal distribution and exhibited homoscedasticity were further compared to control values using a 1-way analysis of variance (ANOVA) with a nested design with tanks nested within treatments. In the case of shrimp and salmon growth and length measurements where varying tank n-values excluded the use of a nested design, a 2-way ANOVA design was applied with a forced Tukey's post-hoc analysis of tanks nested within treatment (noise and control) to test for tank effect in a pairwise manner. SGR was calculated as a whole tank value (as individuals were not tagged) and data tested using a 1-way ANOVA. All statistical analyses were performed using SigmaPlot Software v. 11.0 and RealStatistics Software templates for Excel 2019.

\section{RESULTS}

\subsection{Sound playback}

The ambient noise (in control tanks) in both the shrimp Litopenaeus vannamei and salmon Salmo salar playback RAS was low, and the shrimp and sound playback significantly increased the sound within the treatment tanks across the entire frequency range (Fig. 1). The playback sound for shrimp was missing a low frequency peak at $200 \mathrm{~Hz}$; the rest of the bandwidth closely matched the source file

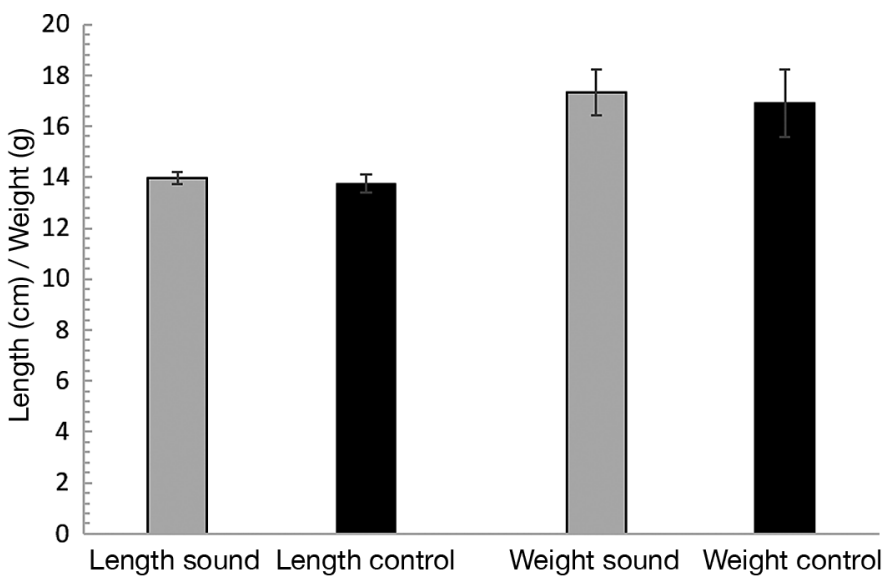

Fig. 2. Whiteleg shrimp mean length $(\mathrm{cm})$ and weight $(\mathrm{g})$ (tank means, $\mathrm{N}=3$ tanks per treatment) in sound and control treatments at experimental completion after $8 \mathrm{wk}$. Error bars $=1 \mathrm{SD}$
(Fig. 1A). Playback for the salmon treatment closely aligned with the source file for each treatment (Fig. 1B).

\subsection{Shrimp growth and survival}

Shrimp survival across treatments and controls was $67 \pm 9 \%$ (mean \pm SD) with survival slightly lower in control tanks $(65 \pm 9 \%)$, as opposed to sound treatment $(69 \pm 9 \%)$. At experimental completion, shrimps in the sound treatment weighed $17.3 \pm 0.9 \mathrm{~g}$ and were $14.0 \pm 0.2 \mathrm{~cm}$ in length. Shrimp from the control treatment exhibited very similar growth rates, weighing $16.9 \pm 1.3 \mathrm{~g}$ and measuring $13.8 \pm$ $0.3 \mathrm{~cm}$ (Fig. 2). Shrimp weight and length did not differ significantly between control and sound exposure treatments $\left(F_{1,195}=1.095, \mathrm{p}=0.297\right.$ and $F_{1,195}=2.056$, $\mathrm{p}=0.153$, respectively). Pairwise comparison of tanks within treatment and controls revealed no significant tank effect for shrimp weight with the greatest mean difference within controls at Tank 3 vs. Tank $2(\mathrm{~N}=3$; $Q=3.246, \mathrm{p}=0.056)$ and within sound treatments at Tank 1 vs. $2(\mathrm{~N}=3 ; Q=2.315, \mathrm{p}=0.230)$. For length, the greatest mean difference within controls is Tank 3 vs. Tank $2(\mathrm{~N}=3 ; Q=3.217, \mathrm{p}=0.059)$, within sound treatments is $(\mathrm{N}=3 ; Q=2.612, \mathrm{p}=0.154)$.

\subsection{Shrimp immune and stress response}

Activity of phenoloxidase was highly variable across all measurements and treatments. A total of 21 technical replicates in the control and 24 technical replicates in the sound treatment were analyzable for activity: means were calculated from technical replicates to provide values corresponding to individual phenoloxidase activity of 7 control and 9 soundexposed animals, respectively. Activity was higher amongst shrimps in the control $\left(287.9 \pm 113.8 \mathrm{U} \mathrm{ml}^{-1}\right.$, mean $\pm \mathrm{SD}$ ) than for those in the sound treatment $\left(184.3 \pm 116.3 \mathrm{U} \mathrm{ml}^{-1}\right)$, but values did not differ significantly across treatments $\left(F_{1,15}=1.669, \mathrm{p}=0.265\right)$ with no tank effect (Tank [Treatment] $F_{4,16}=1.632$, $\mathrm{p}=0.246$; Fig. 3)

\subsection{Shrimp total haemocyte count (THC) and differential haemocyte count (DHC)}

Total haemocyte counts differed between control and sound-exposure treatment with animals from the sound-exposure treatment $(241.57 \pm 34.1)$ exhibiting 


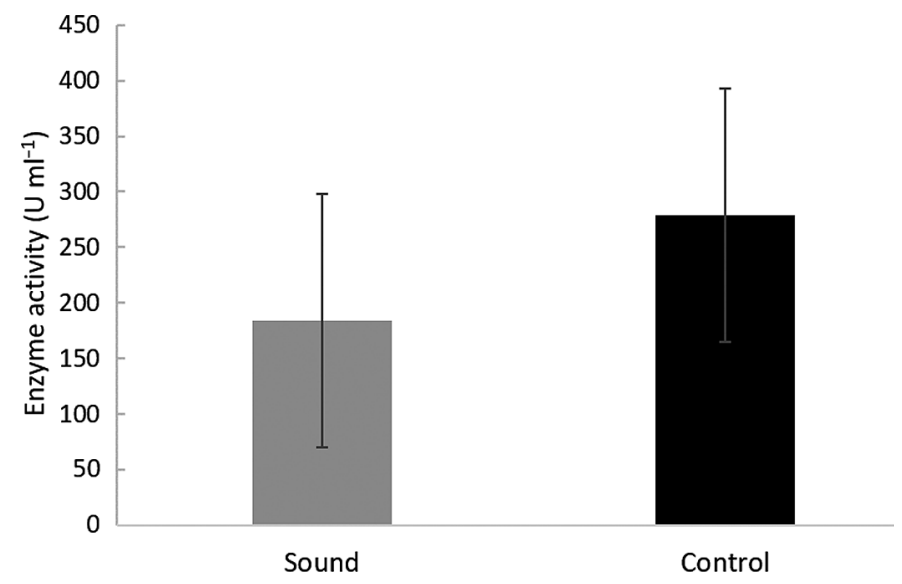

Fig. 3. Whiteleg shrimp haemolymph phenoloxidase mean activity $\left(\mathrm{U} \mathrm{m}^{-1}\right)$ (individual animal means, $\mathrm{n}=7$ and 9, respectively) in sound and control treatments at experimental completion after $8 \mathrm{wk}$. Error bars $=1 \mathrm{SD}$

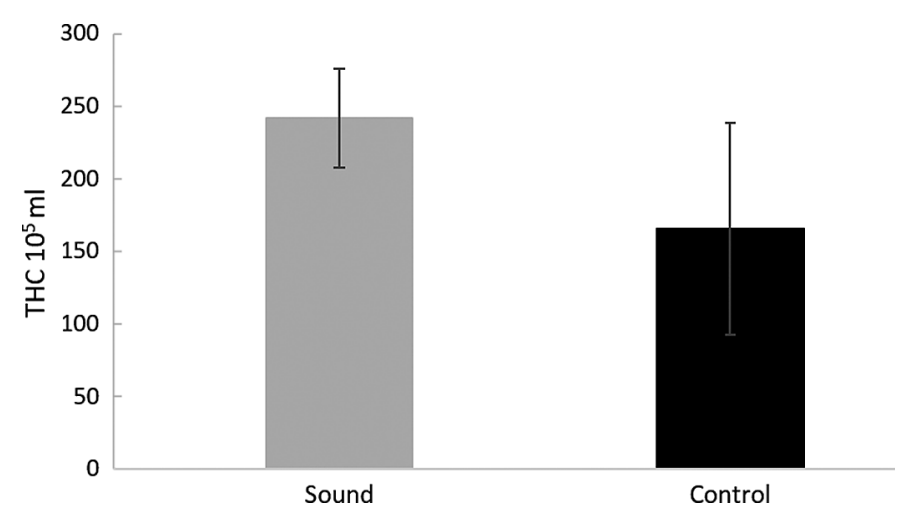

Fig. 4. Whiteleg shrimp total haemocyte count (THCabsolute) (individual animal means, $\mathrm{n}=9$ for both) in sound and control treatments at experimental completion after $8 \mathrm{wk}$. Error bars $=1 \mathrm{SD}$

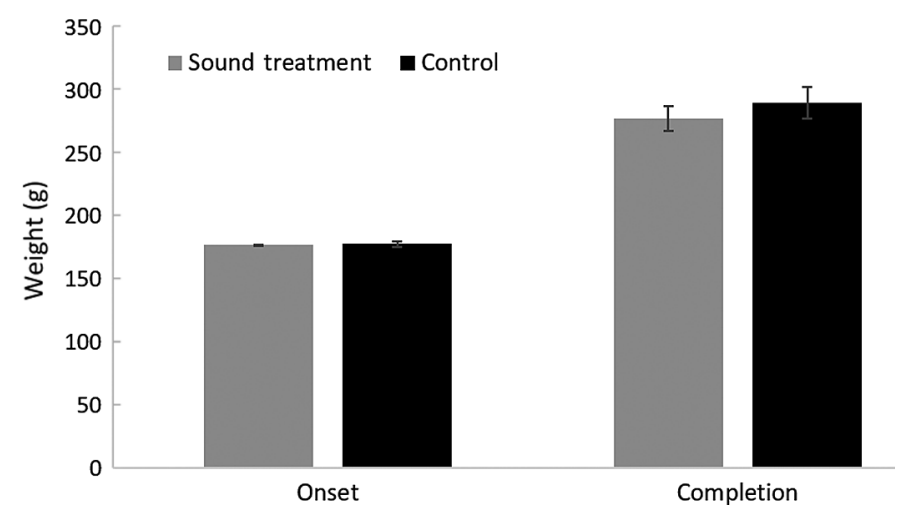

Fig. 5. Atlantic salmon Salmo salar mean weight (g) (tank means, $n=3$ ) in sound and control treatments at experimental onset and at completion after $8 \mathrm{wk}$. Error bars $=1 \mathrm{SD}$ higher values than the controls $(165.40 \pm 73.1)$, although differences between groups were not statistically significant $\left(F_{1,17}=1.154, \mathrm{p}=0.343\right)$ with no tank effect (Tank [Treatment] $F_{4,17}=2.248, \mathrm{p}=0.124$ ).

The differential fractions of counted haemocytes differed between treatments, with the sound treatment $\left(29.88 \times 10^{5} \pm 2.3 \times 10^{5}\right.$ cells $\left.\mathrm{ml}^{-1}\right)$ exhibiting a higher overall first fraction (estimated hyaline cell fraction) in absolute cell count compared to the control $\left(25.50 \times 10^{5} \pm 3.2 \times 10^{5}\right.$ cells ml-1 $)$. However, differences were not significant $\left(F_{1,17}=0.077, \mathrm{p}=\right.$ 0.794) with no tank effect (Tank [Treatment] $F_{4,17}=$ $0.367 ; \mathrm{p}=0.827$ ).

In the second fraction of larger cells (estimated semi-granular and granular cell count), the soundexposure treatment exhibited higher cell counts $\left(211.7 \times 10^{5} \pm 32.5 \times 10^{5}\right.$ cells ml $\left.{ }^{-1}\right)$ than control animals $\left(139.9 \times 10^{5} \pm 64.9 \times 10^{5}\right.$ cells ml $\left.{ }^{-1}\right)$. However, results did not differ significantly $\left(F_{1,17}=1.296, \mathrm{p}=\right.$ 0.318 ) between treatment and control, and no tank effect was detected (Tank [Treatment] $F_{4,17}=2.281$, $\mathrm{p}=0.121$ (Fig. 4).

\subsection{Salmon growth and survival}

Salmon survival was similar between controls (98 \pm $3 \%)$ and sound treatments $(95 \pm 5 \%$ mean \pm SD). Salmon final length was also similar between treatments (sound: $29.2 \mathrm{~cm} \pm 0.1$ mean $\pm \mathrm{SD}$; control: $29.3 \pm$ $0.2 \mathrm{~cm})\left(F_{1,115}=0.212, \mathrm{p}=0.646\right)$. Pairwise comparison of tanks within treatment and controls revealed no significant tank effect for salmon length with the greatest mean difference within controls in Tank 1 vs. Tank $3(\mathrm{~N}=3 ; Q=1.494, \mathrm{p}=0.543)$ and within sound treatments in Tank 1 vs. $2(\mathrm{~N}=3 ; Q=1.987, \mathrm{p}=0.342)$.

Mean $( \pm 1 \mathrm{SD})$ final salmon weight in sound treatments $(277.9 \pm 9.7 \mathrm{~g})$ was slightly lower than in the controls $(290.2 \pm 12.5 \mathrm{~g})$ but was not significantly different $\left(F_{1,110}=1.632, \mathrm{p}=0.204\right)$. Pairwise comparison of tanks within treatment and controls revealed no significant tank effect for salmon weight, with the greatest mean difference within controls in Tank 2 vs. Tank 1 ( $\mathrm{N}=3 ; Q=2.561, \mathrm{p}=0.171)$ and within sound treatments in Tank 1 vs. $3(\mathrm{~N}=3 ; Q=1.987, \mathrm{p}=$ 0.342) (Fig. 5).

Mean final salmon condition factor $(K)$ was higher in control tanks $(1.14 \pm 0.03)$ than in sound treatments $(1.11 \pm 0.03)$ but values were not significantly different $\left(F_{1,110}=3.329 ; \mathrm{p}=0.071\right)$. Pairwise comparison of tanks within treatment and controls revealed no significant tank effect for $K$ with the greatest mean difference within controls in Tank 1 vs. Tank 3 
$(\mathrm{N}=3 ; Q=2.328, \mathrm{p}=0.231)$ and within sound treatments in Tank 2 vs. 1 ( $\mathrm{N}=3 ; Q=2.430, \mathrm{p}=0.203)$. Mean SGR was also higher in control tanks (0.87 \pm $0.07)$ than in sound treatments $(0.80 \pm 0.07)$ but values did not differ significantly between treatments $\left(F_{1,3}=4.724, \mathrm{p}=0.118\right)$.

\subsection{Salmon blood analyses and histology}

All blood and histological parameters from poolsampled animals (at experimental onset) were within normal bounds for juvenile Atlantic salmon (Table 1). At experimental completion, all blood and histological parameters remained within normal or expected values. Blood glucose and hematocrit levels increased from the experimental outset to final sampling in both treatment and controls. Mean blood glucose concentration was higher in sound treatments $\left(112.8 \pm 27.9 \mathrm{mg} \mathrm{l}^{-1}\right)$ than in the controls (96.7 $\left.\pm 12.5 \mathrm{mg} \mathrm{l}^{-1}\right)$; however, values were not significantly different $\left(F_{1,17}=0.831, \mathrm{p}=0.413\right)$ with no tank effect (Tank [Treatment] $F_{4,17}=2.825, \mathrm{p}=0.072$ ). Lactate in sound tanks $\left(1.7 \pm 0.5 \mathrm{mmol} \mathrm{l}^{-1}\right)$ was lower than in controls $\left(2.0 \pm 0.5 \mathrm{mmol} \mathrm{l}^{-1}\right)$ but values did not differ significantly $\left(F_{1,15}=0.144, \mathrm{p}=0.725\right)$ with no tank effect (Tank [Treatment] $F_{4,15}=3.000 ; \mathrm{p}=0.072$ ). Treatment $\mathrm{pH}(7.2 \pm 0.1)$ did not differ significantly from controls $(7.3 \pm 0.1)\left(F_{1,17}=0.333, \mathrm{p}=0.594\right)$ with no tank effect (Tank [Treatment] $F_{4,17}=0.928, \mathrm{p}=$ 0.479). Hematocrit in treatment fish $(34.1 \pm 3.3 \%)$ did not differ significantly $\left(F_{1,17}=0.276, \mathrm{p}=0.626\right)$ from controls $(34.6 \pm 4.2 \%)$ with no tank effect (Tank [Treatment] $F_{4,17}=0.317, \mathrm{p}=0.860$ ). Liver weight in Treatment fish $(3.9 \pm 0.4 \mathrm{~g})$ did not differ significantly $\left(F_{1,17}=0.186, \mathrm{p}=0.688\right)$ from controls $(4.0 \pm 0.2 \mathrm{~g})$ with no tank effect (Tank [Treatment] $F_{4,17}=0.352, \mathrm{p}=$ $0.837)$. Hepatosomatic index in Treatment fish $(1.5 \pm$ $0.02 \%)$ did not differ significantly $\left(F_{1,17}=0.236, \mathrm{p}=\right.$ $0.652)$ from controls $(1.4 \pm 0.02 \mathrm{~g})$ with no tank effect (Tank [Treatment] $F_{4,17}=2.024, \mathrm{p}=0.154$ ).
Plasma cortisol levels at experimental completion were highly variable and higher in sound-exposure treatments $\left(34.7 \pm 15.2 \mathrm{ng} \mathrm{ml}^{-1}\right)$ than in controls $\left(30.44 \pm 45.8 \mathrm{ng} \mathrm{ml}^{-1}\right)$ but did not differ significantly between treatments $\left(F_{1,17}=0.023, \mathrm{p}=0.886\right)$ with no tank effect (Tank [Treatment] $F_{4,17}=2.108, \mathrm{p}=0.142$; Table 1).

\section{DISCUSSION}

High-intensity soundscapes created by aquaculture production systems remain poorly understood. There is a dearth of information on their effects on growth performance, stress and immune status and overall welfare of the high-value animals exposed to them. The current study developed and applied novel exposure experiments using playback of recordings of commercial aquaculture production systems for high-value global aquaculture species Atlantic salmon Salmo salar and whiteleg shrimp Litopenaeus vannamei. This study revealed no measurable impact on cultured animals exposed to aquaculture system soundscapes over a period of $8 \mathrm{wk}$. The measures applied in the current study are broad and were chosen to represent key performance, metabolic and immunological parameters of interest for commercial aquaculture production research. Herein, they are discussed in relation to previous behavioural and metabolic studies of sound impacts on fish and invertebrates.

The sounds generated by both of these aquaculture systems was relatively quiet (128 and $127 \mathrm{~dB}$ re $1 \mu \mathrm{Pa}$ ) when compared to other anthropogenic sources of sound (Radford \& Slater 2019). For example, commercial ships have source levels ranging from 175 to $192 \mathrm{~dB}$ re $1 \mathrm{\mu Pa}^{2}$ in the frequency band 20 to $1000 \mathrm{~Hz}$ (McKenna et al. 2013) and pile-driving activity generates sound exceeding $170 \mathrm{~dB}$ re $1 \mu \mathrm{Pa}$ (Würsig et al. 2000). The sounds generated by these 2 systems are more consistent with recreational boat noise, which

Table 1. Mean ( $\pm 1 \mathrm{SE})$ Atlantic salmon blood and histological parameters as measure at experimental onset and at experimental completion at $8 \mathrm{wk}$ in sound treatment (exposure to $127 \mathrm{~dB}$ re $1 \mu \mathrm{Pa}$ ) and control (exposure to <90 dB re $1 \mu \mathrm{Pa}$ ). HSI: hepatosomatic index; n.a. indicates value not available (at experimental onset). $\mathrm{N}=9$ in all cases except lactate ( $\mathrm{N}=8$ for both control and sound treatment)

\begin{tabular}{|lcccccccc|}
\hline $\begin{array}{l}\text { Physiological } \\
\text { parameter }\end{array}$ & $\begin{array}{c}\text { Lactate } \\
\left(\mathrm{mmol} \mathrm{l}^{-1}\right)\end{array}$ & $\mathrm{pH}$ & $\begin{array}{c}\text { Liver } \\
\text { weight }(\mathrm{g})\end{array}$ & $\begin{array}{c}\text { Fish } \\
\text { weight }(\mathrm{g})\end{array}$ & $\begin{array}{c}\text { HSI } \\
(\%)\end{array}$ & $\begin{array}{c}\text { Glucose } \\
\left(\mathrm{mg} \mathrm{l}^{-1}\right)\end{array}$ & $\begin{array}{c}\text { Haematocrit } \\
(\%)\end{array}$ & $\begin{array}{c}\text { Plasma } \\
\left.\mathrm{cortisol}(\mathrm{ng} \mathrm{ml})^{-1}\right)\end{array}$ \\
\hline Exp. onset & $1.9(0.9)$ & $7.4(0.1)$ & n.a. & $179.8(60.4)$ & n.a. & $62.8(12.2)$ & $16.6(10.4)$ & n.a. \\
Sound & $1.7(0.5)$ & $7.2(0.1)$ & $3.9(0.4)$ & $262.0(44.1)$ & $1.5(0.02)$ & $112.8(27.9)$ & $34.1(3.3)$ & $34.7(15.2)$ \\
Control & $2.0(0.5)$ & $7.3(0.1)$ & $4.0(0.2)$ & $285.6(34.8)$ & $1.4(0.02)$ & $96.7(12.5)$ & $34.6(4.2)$ & $30.44(45.8)$ \\
\hline
\end{tabular}


ranges from 111 to $135 \mathrm{~dB}$ re $1 \mu \mathrm{Pa}$ depending on engine type and distance to the source (Nedelec et al. 2017, Mensinger et al. 2018). Chronic or acute sound exposure can result in different responses in terms of larval behaviour. For example, Nedelec et al. (2016) showed that the coral reef fish, Dascyllus trimaculatus, habituated to chronic exposure to recreation boat sound, but showed a significant stress response to multiple acute exposures to the same sound. Hence, the lack of stress responses observed both in whiteleg shrimp and Atlantic salmon in the present study maybe due to habituation to the sound playback.

Filiciotto et al. (2013) measured increased oxidative stress response in juvenile sea bream after $40 \mathrm{~d}$ exposure to onshore aquaculture sounds ranging up to $126 \mathrm{~dB}$ re $1 \mu \mathrm{Pa}$ and in control tanks with similar continuous sounds ranging up to $115 \mathrm{~dB}$ re $1 \mu \mathrm{Pa}$. However, in the same study, reduced oxidative stress and higher growth performance was measured in animals exposed to highly variable soundscapes representing offshore aquaculture conditions and ranging up to $146 \mathrm{~dB}$ re $1 \mu \mathrm{Pa}$ (Filiciotto et al. 2013). Wysocki et al. (2006) were also able to detect significant differences in water cortisol concentration for European perch and common carp after short-term exposure to ship noise at $153 \mathrm{~dB}$ re $1 \mu \mathrm{Pa}$. In the present study, 8 wk exposure to levels near $130 \mathrm{~dB}$ re $1 \mu \mathrm{Pa}$ did not cause significant increases in plasma cortisol in Atlantic salmon and did not significantly affect prophenoloxidase response in whiteleg shrimp. Behavioural and physiological hearing thresholds vary widely among species (e.g. Hawkins \& Johnstone 1978, Amoser \& Ladich 2005); however, the sound and playback levels in the current study are well within the hearing range of Atlantic salmon and that determined for a similar shrimp species, the common shrimp Palaemon serratus (Hawkins \& Johnstone 1978, Amoser \& Ladich 2005, Lovell et al. 2005, Ladich \& Fay 2013). Hearing capacity in rapidly growing salmon may be reduced due to otolith malformation (Reimer et al. 2016, 2017). Nonetheless, it appears unlikely that the animals in the current study did not perceive the playback sounds at all. However, it is possible that the markedly $(\sim 14 \mathrm{~dB}$ re $1 \mu \mathrm{Pa})$ lower and less variable (compared to previous experiments, e.g. Wysocki et al. [2006] used ship sounds ranging from 128 to $162 \mathrm{~dB}$ ) SPLs in the current study did not elicit the strong behavioural or physiological responses observed in other studies (Wysocki et al. 2006). The SPLs used in the current study represent the prevailing acoustic habitat at aquaculture sites and the playbacks are actual recordings of those sites. These data may provide first reference values for maximum SPLs at sites and may assist in the development of guidelines to reduce stressful sound events.

It remains unclear whether Atlantic salmon and whiteleg shrimp habituated to the sound exposure in the present study of $56 \mathrm{~d}$. A normalization of blood cortisol levels may have occurred as animals become habituated to higher sound levels. The current results suggest rather that the sound levels do not result in a cortisol response in the first instance. The equal growth, survival and metabolic responses indicate that the animals did not suffer significant or disadvantageous stress over the experimental period. In aquaculture systems, where exposure to soundscapes is a permanent and unavoidable factor for the fish, the longer-term response is highly applicable. Wysocki et al. (2006) suggested that high-level Gaussian or white noise at $153 \mathrm{~dB}$ re $1 \mu \mathrm{Pa}$ did not induce a stress response due to the lack of variability in noise level and type. Filiciotto et al. (2013) also used 5 alternating sounds at 5 varying SPLs to simulate offshore aquaculture noise and recorded reduced oxidative stress and increased growth in sea bream exposed for several months when sounds were more variable, despite being louder. The recordings applied in the current study are variable, particularly the salmon farm recordings. It is probable that the shrimp RAS system recording is not only quieter but also markedly less variable than those used in previous exposure studies (Radford \& Slater 2019). However, this resembles the actually occurring sounds in German shrimp production systems.

High levels of sound exposure from pile-driving cause large-scale (hundreds to thousands of metres) avoidance responses in several salmonids and smaller scales (1 to $10 \mathrm{~m}$ ) in shrimp, including whiteleg shrimp (Feist 1991, Zhou et al. 2016). In wild organisms, noise avoidance can markedly affect feeding, breeding or options for predator avoidance. While breeding and predators should play small roles in grow-out aquaculture, feeding disturbance due to sound would result in growth and survival impairment. In the current study, such impairment was not observed: growth rates were excellent for both species and did not differ between control and treatments. The current results for whiteleg shrimp strongly contradict Lagardère (1982), who reported that sound levels of $30 \mathrm{~dB}$ re $1 \mu \mathrm{Bar} / \mathrm{Hz}$ at 25 to $400 \mathrm{~Hz}$ frequency range resulted in lower growth and reproduction rates and higher aggression levels with poorer feeding in tank-reared brown shrimp Crangon crangon. Apart from differences in claw count and the tail segment shape, brown shrimp do not 
exhibit marked morphological differences to whiteleg shrimp. However, the species is much smaller than whiteleg shrimp $(<30 \%$ of adult size $)$ and exhibits different daytime behaviour in tanks with a distinct burying activity during high light periods (M. Slater pers. obs.). Responses of aquaculture species to sound, particularly variable sound, may be unexpected and complex, even positive in terms of feeding response. In a conditioning study, Meier \& Horseman (1977) were able to use daily 20 min buzzer sounds to induce a feeding response in blue tilapia Oreochromis aureus, which resulted in significant growth improvements over control fish. This result was obtained with robust, grow-out ready fish, as in the current study. Such robustness may not be given in earlier life stages, which may point to future areas of research.

Previous studies with larval fish indicate that sound exposure can affect growth, survival, reproductive success and even levels of aggression. Banner \& Hyatt (1973) increased SPLs by $20 \mathrm{~dB}$ above controls and found reduced growth in sheepshead minnow Cyprinodon variegatus and longnose killifish Fundulus similis. In Atlantic cod Gadus morhua larvae, early hatched animals showed more rapid egg-sac depletion, increased startling events and reduced growth after $2 \mathrm{~d}$ of exposure to randomised and continuous sounds compared to a sound-free control (Nedelec et al. 2015). However, all growth and survival measures converged between treatment and controls after $16 \mathrm{~d}$ of exposure. The impact of sound on juvenile crustaceans has not been investigated, but the present results indicate this may be an area of future interest in terms of aquaculture soundscapes and limit-setting for future SPLs in hatcheries.

The current results indicate that actual soundscapes from sea pen and recirculating aquaculture facilities do not negatively affect growth, metabolism, health or immune response in the high-value species studied herein during the grow-out phase. Where soundscapes exceed the SPLs applied herein, the literature indicates that stress responses can be expected. The SPLs tested herein should act as threshold maximum SPLs and can be applied in a precautionary approach to ensuring soundscapes suitable for ensuring animal welfare is addressed in terms of sound in aquaculture. Further research regarding the impact on early juvenile animals particularly in tank/recirculating systems in hatcheries is recommended. Studies on sensitive adult stages such as broodstock at varying stages in the breeding cycle and on aquaculture species of potentially high sensitivity are recommended.
Acknowledgements. The authors thank Green Aqua Farming/Cara Royale in Germany and New Zealand King Salmon for access and logistical support. Thanks also to the independent reviewers for their time and valuable input which greatly improved the manuscript. This research was funded by the Royal Society of New Zealand and the German Federal Ministry of Education and Research within the Framework of the New Zealand-Germany Scientific Exchange Programme.

\section{LITERATURE CITED}

Amoser S, Ladich F (2005) Are hearing sensitivities of freshwater fish adapted to the ambient noise in their habitats? J Exp Biol 208:3533-3542

Ashley PJ (2007) Fish welfare: current issues in aquaculture. Appl Anim Behav Sci 104:199-235

Banner A, Hyatt M (1973) Effect of noise on eggs and larvae of 2 estuarine fishes. Trans Am Fish Soc 102:134-136

* Bart AN, Clark J, Young J, Zohar Y (2001) Underwater ambient noise measurements in aquaculture systems: a survey. Aquacult Eng 25:99-110

Craven A, Carton AG, McPherson CR, McPherson G (2009) Determining and quantifying components of an aquaculture soundscape. Aquacult Eng 41:158-165

Feist BE (1991) Potential impacts of pile driving on juvenile pink (Oncorhynchus gorbuscha) and chum (O. keta) salmon behavior and distribution. University of Washington, Seattle, WA

Filiciotto F, Giacalone VM, Fazio F, Buffa G and others (2013) Effect of acoustic environment on gilthead sea bream (Sparus aurata): sea and onshore aquaculture background noise. Aquaculture 414-415:36-45

Filiciotto F, Vazzana M, Celi M, Maccarrone V and others (2016) Underwater noise from boats: measurement of its influence on the behaviour and biochemistry of the common prawn (Palaemon serratus, Pennant 1777). J Exp Mar Biol Ecol 478:24-33

Filiciotto F, Cecchini S, Buscaino G, Maccarrone V, Piccione G, Fazio F (2017) Impact of aquatic acoustic noise on oxidative status and some immune parameters in gilthead sea bream Sparus aurata (Linnaeus 1758) juveniles. Aquacult Res 48:1895-1903

*Fuchs VI, Schmidt J, Slater MJ, Buck BH, Steinhagen D (2017) Influence of immunostimulant polysaccharides, nucleic acids, and Bacillus strains on the innate immune and acute stress response in turbots (Scophthalmus maximus) fed soy bean- and wheat-based diets. Fish Physiol Biochem 43:1501-1515

Hawkins AD, Johnstone ADF (1978) The hearing of the Atlantic salmon, Salmo salar. J Fish Biol 13:655-673

* Huang J, Yang Y, Wang A (2010) Reconsideration of phenoloxidase activity determination in white shrimp Litopenaeus vannamei. Fish Shellfish Immunol 28: $240-244$

Joenson R (2016) Large smolts in salmon farming. Sjávarútvegsráðstefnan 2016, Hörpu, Rekjavik

* Ladich F, Fay RR (2013) Auditory evoked potential audiometry in fish. Rev Fish Biol Fish 23:317-364

KLagardère JP (1982) Effects of noise on growth and reproduction of Crangon crangon in rearing tanks. Mar Biol 71:177-185

Kovell JM, Findlay MM, Moate RM, Yan HY (2005) The hearing abilities of the prawn Palaemon serratus. Comp 
Biochem Physiol A Mol Integr Physiol 140:89-100

Lucas J, Southgate P (2012) Aquaculture: farming aquatic animals and plants. Wiley-Blackwell, West Sussex

McCauley RD, Fewtrell J, Popper AN (2003) High intensity anthropogenic sound damages fish ears. J Acoust Soc Am 113:638-642

McKenna MF, Wiggins SM, Hildebrand JA (2013) Relationship between container ship underwater noise levels and ship design, operational and oceanographic conditions. Sci Rep 3:1760

Meier AH, Horseman ND (1977) Stimulation and depression of growth, fat storage and gonad weight by daily stimulus in the teleost fish, Tilapia aurea. Proc World Mariculture Soc 8:135-143

Mensinger AF, Putland RL, Radford CA (2018) The effect of motorboat sound on Australian snapper Pagrus auratus inside and outside a marine reserve. Ecol Evol 8: 6438-6448

Nedelec SL, Simpson SD, Morley EL, Nedelec B, Radford AN (2015) Impacts of regular and random noise on the behaviour, growth and development of larval Atlantic cod (Gadus morhua). Proc Biol Sci 282:20151943

Nedelec SL, Mills SC, Lecchini D, Nedelec B, Simpson SD, Radford AN (2016) Repeated exposure to noise increases tolerance in a coral reef fish. Environ Pollut 216: 428-436

Neo YY, Hubert J, Bolle LJ, Winter HV, Slabbekoorn H (2018) European seabass respond more strongly to noise exposure at night and habituate over repeated trials of sound exposure. Environ Pollut 239:367-374

Owens L, O'Neill A (1997) Use of a clinical cell flow cytometer for differential counts of prawn Penaeus monodon haemocytes. Dis Aquat Org 31:147-153

Popper AN (1972) Pure-tone auditory thresholds for the carp, Cyprinus carpio. J Acoust Soc Am 52:1714-1717

Popper AN (2003) Effects of anthropogenic sounds on fishes. Fisheries 28:24-31

Radford C, Slater M (2019) Soundscapes in aquaculture systems. Aquacult Environ Interact 11:53-62

Editorial responsibility: Per Gunnar Fjelldal,

Matredal, Norway
Reimer $T$, Dempster $T$, Warren-Myers $F$, Jensen AJ, Swearer SE (2016) High prevalence of vaterite in sagittal otoliths causes hearing impairment in farmed fish. Sci Rep 6:25249

* Reimer T, Dempster T, Wargelius A, Fjelldal PG and others (2017) Rapid growth causes abnormal vaterite formation in farmed fish otoliths. J Exp Biol 220:2965-2969

Reiser S, Schroeder JP, Wuertz S, Kloas W, Hanel R (2010) Histological and physiological alterations in juvenile turbot (Psetta maxima, L.) exposed to sublethal concentrations of ozone-produced oxidants in ozonated seawater. Aquaculture 307:157-164

Sand O, Enger PS, Karlsen HE, Knudsen F, Kvernstuen T (2000) Avoidance responses to infrasound in downstream migrating European silver eels, Anguilla anguilla. Environ Biol Fishes 57:327-336

F Slabbekoorn H, Bouton N (2008) Soundscape orientation: a new field in need of sound investigation. Anim Behav 76: E5-E8

Slater M (2018) Whiteleg shrimp postlarvae supply in Europe: the risk of single sources of supply of fundamental inputs. J World Aquacult Soc 49:802-804

Wolff D (1967) Das Hoervermoegen des Flußbarsches (Perca fluviatilis L.). Biol Zent Bl 86:449-460

*Würsig B, Greene CR, Jefferson TA (2000) Development of an air bubble curtain to reduce underwater noise of percussive piling. Mar Environ Res 49:79-93

Wysocki LE, Dittami JP, Ladich F (2006) Ship noise and cortisol secretion in European freshwater fishes. Biol Conserv 128:501-508

Xian JA, Wang AL, Tian JX, Huang JW, Ye CX, Wang WN, Sun RY (2009) Morphologic, physiological and immunological changes of haemocytes from Litopenaeus vannamei treated by lipopolysaccharide. Aquaculture 298: 139-145

Zhou WZR, Xu XM, Tu XB, Chen YG (2016) Preliminary exploration for effects of sound stimulus on the movement behavior of Litopenaeus vannamei. 2016 Ieee/Oes China Ocean Acoustics Symposium, Harbin

Submitted: July 12, 2019; Accepted: February 19, 2020

Proofs received from author(s): April 8, 2020 